\title{
A new approach for leptomeningeal metastases: chemotherapy administered through lumbar intrathecal port
}

\author{
Un nuevo abordaje para el tratamiento de las metástasis leptomeníngeas: uso de catéter \\ implantado para el suministro de quimioterapia vía intratecal lumbar
}

Savas COMLEK' ${ }^{1}$ Sezer SAGLAM²

\begin{abstract}
Background: Intrathecal chemotherapy is a local therapeutic modality used for treatment of leptomeningeal metastases. However, the techniques currently used, i.e. repeated lumbar puncture and Ommaya reservoir, have certain disadvantages. Lumbar intrathecal port (LIP) placement is a relatively novel technique, which has been used for pain management in cancer patients. Objective: To investigate the use of LIP for intrathecal administration of chemotherapeutic agents in patients with leptomeningeal metastases. Methods: Retrospective study of 13 patients treated with intrathecal chemotherapy for secondary leptomeningeal involvement of a primary solid tumor were included in this retrospective study. The patients received intrathecal chemotherapy through a LIP. Results: The patients received a total of 123 intrathecal chemotherapy doses. No grade 3-4 toxicity, technical problem or severe complication developed. During a median of 136 days of follow-up (range, 67-376 days), 12 patients died (92.3\%). The treatment resulted in symptom improvement in all patients and self-rated overall health and quality of life improved, compared with baseline. Conclusions: The LIP system, which has been used for intrathecal pain management for decades, appears to offer a safe alternative for intrathecal chemotherapy in patients with leptomeningeal metastases. Further studies are warranted to clarify its potential use in this setting.
\end{abstract}

Keywords: Neoplasm Metastasis; Meningeal Carcinomatosis; Injections, Spinal; Drug Therapy; Spinal Puncture.

RESUMEN

Antecedentes: La quimioterapia intratecal es una modalidad terapéutica local utilizada para el tratamiento de metástasis leptomeníngeas. Sin embargo, las técnicas empleadas actualmente, es decir, las punciones lumbares repetidas y el depósito de Ommaya, tienen algunos inconvenientes. La colocación de un puerto intratecal lumbar (LIP) es una técnica relativamente nueva que se ha utilizado para el tratamiento del dolor en pacientes con cáncer. Objetivo: Investigar el uso de LIP para la administración intratecal de agentes quimioterapéuticos en pacientes con metástasis leptomeníngeas. Métodos: Este estudio retrospectivo incluyó un total de 13 pacientes tratados con quimioterapia intratecal por afectación leptomeníngea secundaria de un tumor sólido primario. Los pacientes recibieron quimioterapia intratecal a través de un LIP. Resultados: Los pacientes recibieron un total de 123 dosis de quimioterapia intratecal. No se desarrolló toxicidad de grado 3-4, ni se presentaron problemas técnicos o complicaciones graves. Durante un promedio de 136 días de seguimiento (rango, 67-376 días), murieron 12 pacientes (92,3\%). El tratamiento dio como resultado una mejoría de los síntomas en todos los pacientes. La salud general autoevaluada y la calidad de vida mejoraron en comparación con los valores iniciales. Conclusiones: El sistema LIP que se ha utilizado para el manejo del dolor intratecal durante décadas, parece ofrecer una alternativa segura para la quimioterapia intratecal en pacientes con metástasis leptomeníngeas. Serán necesarios más estudios para determinar su uso potencial en este ámbito.

Palabras clave: Metástasis de la Neoplasia; Carcinomatosis Meníngea; Inyecciones Espinales; Quimioterapia; Punción Espinal.

\section{INTRODUCTION}

The solid tumors most commonly associated with brain metastases include melanoma, which has the highest propensity to form brain metastasis, and lung, breast, renal cell and gastrointestinal system (GIS) tumors, among which lung and breast tumors give rise to more brain metastases in total ${ }^{1}$. Solid brain metastases may develop in approximately $30 \%$ of patients with

\footnotetext{
'Gayrettepe Florence Nightingale Hastanesi, Department of Anesthesiology and Reanimation, Istanbul, Turkey.

${ }^{2}$ Demiroglu Bilim Üniversitesi, Department of Medical Oncology, Istanbul, Turkey.

SC(D)https://orcid.org/0000-0002-7741-8400; SS(D) https://orcid.org/0000-0001-8954-5792

Correspondence: Savas Comlek; Email: savatc@gmail.com.

Conflict of interests: There is no conflict of interest to declare.

Authors' contributions: SC: drafted and developed the manuscript; SS: critically reviewed and revised it. Both authors read and approved the final manuscript and contributed to the study conception and design, material preparation, data collection and analysis.
}

Received on November 27, 2020; Received in its final form on February 24, 2021; Accepted on February $28,2021$.

(cc) BY 
solid cancers during the course of their disease ${ }^{2}$. It has also been reported that leptomeningeal metastasis (LM) occurs in approximately 3-5\% of all patients with cancer. Moreover, the incidence appears to be rising, particularly due to improved treatment modalities and prolonged survival ${ }^{3.4}$. A diagnosis of LM carries a poor prognosis with estimated median survival of only 2 to 4 months and 4 to 6 weeks with and without treatment, respectively ${ }^{5}$.

For a considerable length of time, no guidelines could be provided for treatment of LM, until 2017, when the first European guidelines were published ${ }^{6}$. The current treatments options for clinical presentations of LM include systemic and intrathecal chemotherapy, brain radiotherapy, spine radiation, immunotherapy and targeted therapy ${ }^{3,6}$. Among these, intrathecal chemotherapy is a local therapeutic modality associated with minimal systemic toxicity, thus allowing simultaneous administration of systemic treatment when necessary. Currently, two main techniques are used for administration of intrathecal chemotherapy. The first is administration through lumbar puncture when necessary, which in turn requires repeated lumbar punctures during the treatment course. The second technique uses an Ommaya reservoir and consists of implantation of an intraventricular catheter and subcutaneous port for the administration of intrathecal therapy ${ }^{6}$. Good distribution of antibodies within the CSF has also been shown when given through lumbar intrathecal injection or through an Ommaya reservoir?.

Implantation of an Ommaya reservoir requires surgery and offers certain advantages in terms of patient compliance, along with better diffusion of the chemotherapeutic agent into the meninges ${ }^{8-10}$. Although implantation of Ommaya reservoirs is considered to be a relatively safe procedure, as shown by acceptable perioperative complication rates ${ }^{10-12}$ and a report on potential applicability among thrombocytopenic patients ${ }^{13}$, their use has also been reported to be associated with significant potential risks. Although image-guided techniques have been used to negate the high risk associated with this procedure, the reported rate of serious complications remains around $8.5 \%^{14,15}$. On the other hand, administration of chemotherapy by means of lumbar puncture occasionally produces complete or partial epidural/subdural leakage and, even with successful lumbar puncture, ventricular chemotherapeutic drug concentration may vary considerably between patients despite similar doses ${ }^{16}$.

Lumbar intrathecal port (LIP) placement is a relatively novel technique based on use of an intrathecal catheter tunneled to a subcutaneous port. This has been used for decades for pain management in cancer patients. LIP has the potential to be safer than Ommaya reservoirs and more reliable than repeated lumbar punctures, and thus may improve both patient satisfaction and compliance ${ }^{17}$.

The aim of this study was to investigate the utility of lumbar intrathecal port (LIP) for intrathecal administration of chemotherapeutic agents in patients with leptomeningeal metastases.

\section{METHODS}

Thirteen patients undergoing treatment at our institution's Oncology department with intrathecal chemotherapy to treat secondary leptomeningeal involvement from a primary solid tumor were included in this retrospective study. All the patients received intrathecal chemotherapy through a LIP. The inclusion criteria were as follows: evidence of leptomeningeal metastasis with both cerebral spinal fluid cytology and neuroradiographic magnetic resonance imaging (including contrast cranial magnetic resonance imaging (MRI), contrast lumbar and ventricular spinal MRI with confirmation of adequate cerebrospinal fluid flow on imaging but without a radionuclide flow study); life expectancy less than three months; no previous non-tumor intervention in cerebrospinal fluid; objective neurological symptoms; and Eastern Cooperative Oncology Group (ECOG) performance status $0-3^{18}$. The study protocol was approved by Demiroglu Bilim University Ethics Committee for Clinical Studies, and the study was conducted in accordance with the Declaration of Helsinki and its later amendments. Due to the retrospective nature of the study and since no patient-identifiable information was included, informed consent was not required.

\section{Implantation of the lumbar intrathecal catheter and subcutaneous port reservoir}

A lumbar intrathecal port (Celsite ${ }^{\circ}$ Spinal Access Ports Systems-B, B. Braun, Germany) was implanted in all patients. Prior to implantation of the lumbar intrathecal catheter and subcutaneous port reservoir, cephalosporin at a dose of $1 \mathrm{~g}$ was administered intravenously for antibiotic prophylaxis. The procedure was done under local anesthesia and conscious sedation with fluoroscopy guidance at the operating theater, with standard anesthesia monitoring. After spinal puncture using an $18 \mathrm{G}$ catheter, the distal part of the spinal catheter was advanced superiorly within the spinal space from the L4-5 or L3-4 level under live fluoroscopy guidance, while the proximal part was passed through the prepared subcutaneous tunnel and was connected to a port that was placed in a subcutaneous pouch. The anterior lower thoracic area was chosen for port placement. After closure of the port pouch with sutures, presence of cerebrospinal fluid was ascertained using a port needle inserted over the skin and, if needed, the catheter localization was confirmed by means of fluoroscopy after administration of radiopaque material. Figures 1 and 2 show the steps of the port placement procedure. The LIP could be used for chemotherapy one hour after implantation. The patients were instructed to rest in bed in the prone position for six hours after the initial LIP placement and for one hour after each intrathecal chemotherapy session, and were then discharged home.

A total of eight doses of chemotherapy were scheduled to be administered on days 1 and 4 of the weeks, for a total of four weeks. In each chemotherapy session, $10 \mathrm{mg}$ of methotrexate 


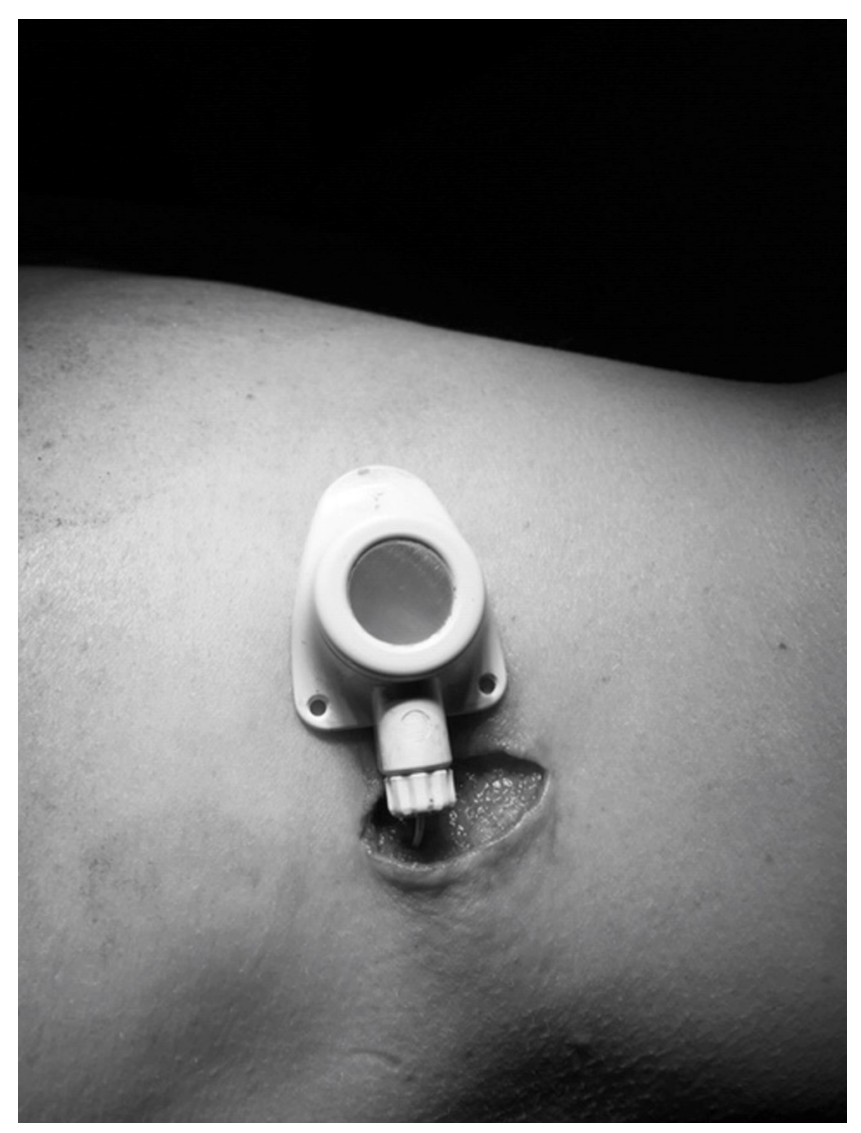

Figure 1. The appearance of the port before it is placed in the subcutaneous pouch.

or $10 \mathrm{mg}$ of thiotepa was given. If indicated, additional monthly doses were administered. After cases of aseptic meningitis were diagnosed in the initially treated group of patients, dexamethasone $4 \mathrm{mg}$ was administered additionally, concomitantly with the intrathecal chemotherapy. The clinical response was assessed once a week or bi-weekly in patients receiving methotrexate or thiotepa, respectively, using clinical evaluation, cerebrospinal fluid cytology and neuroradiological imaging. In addition, toxicity was evaluated using CTCAE v5.0 (Common Terminology Criteria for Adverse Events) ${ }^{19}$.

\section{Assessment of quality of life and health perception}

The following two questions were directed to the patients: 'How do you rate your overall health during the last week?' and 'How do you rate your quality of life during the last week?'. Patients were asked to rate these using a score ranging between 1 and 7, such that 1 indicated the worst condition and 7 indicated an excellent condition.

\section{Statistical analysis}

SPSS version 21 was used for the data analysis. Descriptive data are presented as the mean \pm standard deviation, number (percentage) or median (range), as appropriate. The normality of the continuous variables were tested using the Shapiro-Wilk

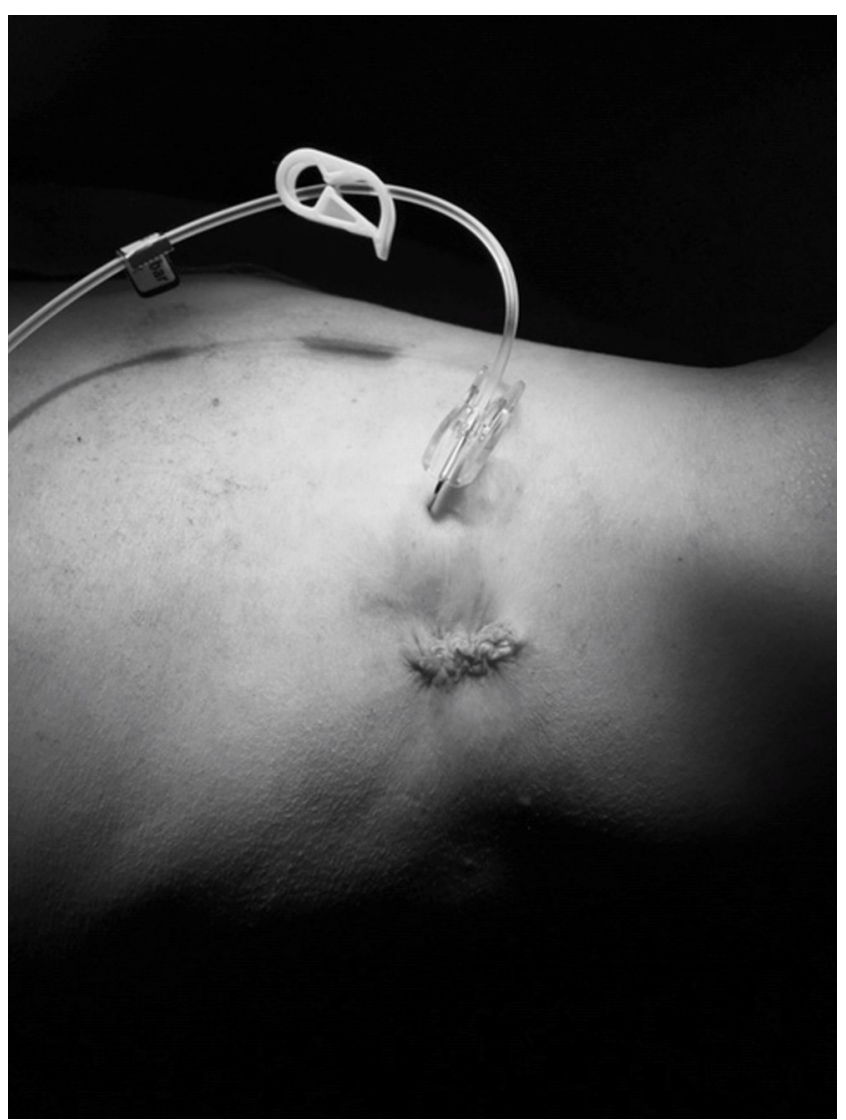

Figure 2. Port needle inserted over the subcutaneously placed port.

test and graphical methods. Quality of life and overall health scores were compared using Student's t test for paired samples or the Wilcoxon signed-rank test, depending on the normality of the data. For survival estimates, the Kaplan-Meier test was used. Mean and median survival times are presented with standard error and $95 \%$ confidence intervals.

\section{RESULTS}

\section{Patients}

Table 1 summarizes the clinical characteristics of the 13 patients. Their median age was 53 years (range, 41-87 y). Seven patients $(53.8 \%)$ were female. The most common primary malignancy was breast cancer $(\mathrm{n}=7)$, followed by lung cancer $(\mathrm{n}=3)$, melanoma $(\mathrm{n}=1)$, mesothelioma $(\mathrm{n}=1)$, and bladder cancer $(\mathrm{n}=1)$. All the patients had accompanying systemic disease. These thirteen patients received a total of 123 intrathecal chemotherapy doses, and 58 cerebrospinal fluid samples were obtained for examination. During the median of 136 days of follow-up (range, 67-376 days), 12 patients died (92.3\%). The median overall survival was $136.0 \pm 41.3$ days (95\% CI, 55.0-217.0) and the mean overall survival was $198.7 \pm 33.7$ days (95\% CI, 132.6-264.9). Figure 3 shows the Kaplan-Meier curve for overall survival. Table 2 shows the radiological and cytological clinical responses. 


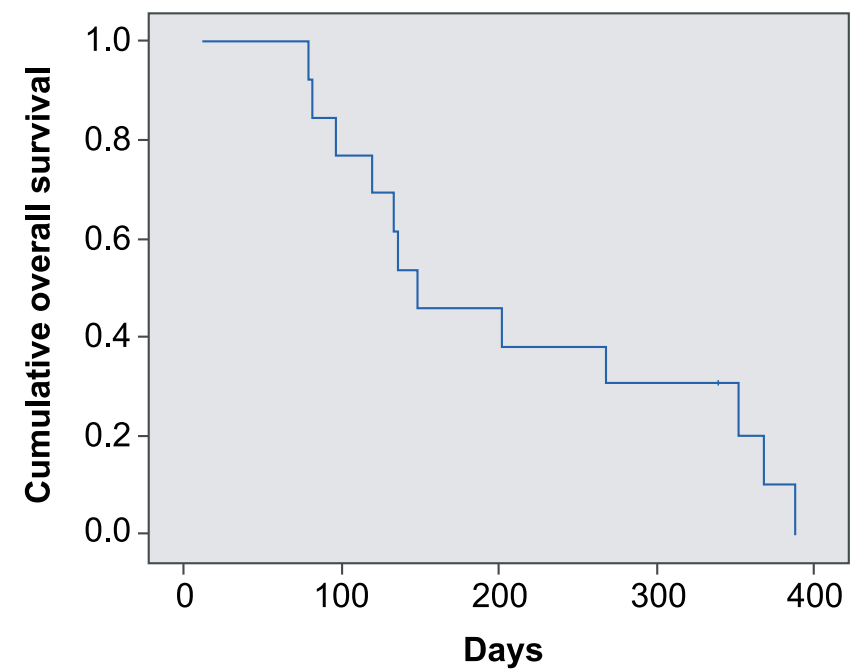

Figure 3. Kaplan-Meier curve for overall survival.

All the patients had received tumor-specific systemic chemotherapy previously. At the time of leptomeningeal metastasis, the primary tumor was in remission in two patients who presented with leptomeningeal metastasis alone; thus, they only received intrathecal chemotherapy plus stereotactic radiosurgery. The remaining 11 patients presented with leptomeningeal metastasis plus additional active disease (extracranial disease or parenchymal brain metastasis), and they received intrathecal chemotherapy plus whole-brain radiotherapy. Two of them also received stereotactic radiosurgery, in addition to their tumor-specific systemic chemotherapy. The tumor-specific chemotherapy agents administered over the disease course are shown in Table 3.

\section{Symptom improvements}

Intrathecal chemotherapy administered through LIP resulted in improvements in neurological condition, pain and symptom control, as well as controlling seizures. Headache and nausea/vomiting were improved in six and five patients, respectively. Table 1 summarizes the details of the symptomatic benefits of the treatment.

\section{Complications}

No patients had grade 3-4 toxicity. No technical problem relating to the LIP or catheter/port-related infection was seen. The initial three patients (23.1\%) developed self-limiting aseptic meningitis due to intrathecal chemotherapy, which responded well to concomitant administration of $4 \mathrm{mg}$ of dexamethasone with the intrathecal chemotherapy. Thereafter, we routinely added dexamethasone to the treatment protocol. The LIP was removed from two patients following the termination of treatment, upon request from the patient and a decision made by the oncologist. In one patient, a foreign-body reaction developed after nine months (Figure 4). The extruded catheter was then placed more deeply, under local anesthesia, and the treatment was continued without problem.

\section{Changes in self-rated health perception and quality of life}

Compared with the baseline, self-rated health perception scores significantly improved (at one month $3.5 \pm 1.1$ and at two months $4.4 \pm 1.3$ vs. baseline $2.4 \pm 0.9 ; \mathrm{p}=0.001$ and $\mathrm{p}<$ 0.001 , respectively). Similar improvements were also evident

Table 1. Patient characteristics.

\begin{tabular}{|c|c|c|c|c|c|c|c|}
\hline Patient No. & Age/sex & Malignancy & Intrathecal CTX & Dosesa & Follow-upb & Status & Improved symptoms \\
\hline 1 & $50 \mathrm{~F}$ & Breast & MTX & 8 & 67 & Died & Mental changes \\
\hline 2 & $69 \mathrm{M}$ & Lung & Thiotepa & 8 & 136 & Died & Neck stiffness, neck pain \\
\hline 3 & $77 \mathrm{M}$ & Bladder & Thiotepa & 8 & 69 & Died & $\begin{array}{l}\text { Neck stiffness, inability to } \\
\text { defecate }\end{array}$ \\
\hline 4 & $41 \mathrm{M}$ & Melanoma & Thiotepa & 6 & 84 & Died & $\begin{array}{l}\text { Seizures (seizure control at } 4 \\
\text { cycles) }\end{array}$ \\
\hline $5^{c}$ & $53 \mathrm{~F}$ & Breast & MTX/Thiotepa & $12 / 5$ & 356 & Died & $\begin{array}{l}\text { Headache, mental changes, neck } \\
\text { stiffness, hyperalgesia }\end{array}$ \\
\hline 6 & $53 \mathrm{M}$ & Mesothelioma & MTX & 8 & 107 & Died & Headache, nausea/vomiting \\
\hline 7 & $53 \mathrm{~F}$ & Breast & MTX & 12 & 376 & Died & Radiculopathy \\
\hline 8 & $51 \mathrm{~F}$ & Breast & MTX & 8 & 190 & Died & Headache, allodynia \\
\hline 9 & $63 \mathrm{~F}$ & Breast & Thiotepa & 8 & 124 & Died & $\begin{array}{l}\text { Allodynia, hyperalgesia, nausea/ } \\
\text { vomiting, sitting disturbance }\end{array}$ \\
\hline 10 & $78 \mathrm{M}$ & Lung & MTX & 8 & 340 & Died & Nausea/vomiting, headache \\
\hline 11 & $87 \mathrm{~F}$ & Breast & MTX & 10 & 121 & Died & $\begin{array}{l}\text { Allodynia, hyperalgesia, nausea/ } \\
\text { vomiting }\end{array}$ \\
\hline 12 & $52 \mathrm{M}$ & Lung & MTX & 14 & 329 & Alive & $\begin{array}{l}\text { Headache, nausea/vomiting, gait } \\
\text { disturbance, seizures }\end{array}$ \\
\hline 13 & $68 \mathrm{~F}$ & Breast & MTX & 8 & 256 & Died & Head pain, neck pain \\
\hline
\end{tabular}

CTX: chemotherapy; MTX: methotrexate; F: female; M: male; aTotal number of intrathecal chemotherapy doses administered; bDays until death or last follow-up; cThis patient initially received 12 doses of MTX and received an additional 5 doses of thiotepa after disease progression. 
Table 2. Cytological and radiological outcomes after intrathecal chemotherapy.

\begin{tabular}{|c|c|c|c|c|}
\hline \multirow[b]{2}{*}{ Patient No. } & \multicolumn{2}{|c|}{ CSF cytology } & \multicolumn{2}{|c|}{ Cerebrospinal MRI } \\
\hline & Baseline & At 1 month & Baseline* & At $1-3$ months \\
\hline 1 & Positive & Negative & Linear & Worsening \\
\hline 2 & Positive & Negative & Linear & Improvement \\
\hline 3 & Positive & Negative & Linear & Stable \\
\hline 4 & Positive & Negative & Linear plus nodular & Stable \\
\hline 5 & Positive & Negative & Linear & Stable \\
\hline 6 & Positive & Suspected positive & Linear & Stable \\
\hline 7 & Positive & Negative & Linear & Improvement \\
\hline 8 & Positive & Negative & Linear & Improvement \\
\hline 9 & Positive & Negative & Linear plus nodular & Improvement \\
\hline 10 & Positive & Negative & Linear & Improvement \\
\hline 11 & Positive & Suspected positive & Linear & Improvement \\
\hline 12 & Positive & Negative & Linear plus nodular & Improvement \\
\hline 13 & Positive & Negative & Linear & Improvement \\
\hline
\end{tabular}

CSF: cerebrospinal fluid; MRI: magnetic resonance imaging; *location of the lesion on MRI (linear and/or nodular).

Table 3. Systemic tumor specific chemotherapy regimens administered during the disease course.

\begin{tabular}{|c|c|c|}
\hline Patient No & Malignancy & Chemotherapy protocol \\
\hline 1 & Breast & $\begin{array}{l}\text { capecitabine, paclitaxel, } \\
\text { vinorelbine }\end{array}$ \\
\hline 2 & Lung & $\begin{array}{l}\text { pemetrexed, vinorelbine, } \\
\text { gemcitabine }\end{array}$ \\
\hline 3 & Bladder & cisplatin, gemcitabine \\
\hline 4 & Melanoma & dabrafenib, temozolomide \\
\hline $5^{*}$ & Breast & $\begin{array}{l}\text { adriamycin, paclitaxel, } \\
\text { cyclophosphamide, } \\
\text { capecitabine, (gemcitabine, } \\
\text { carboplatin)* }\end{array}$ \\
\hline 6 & Mesothelioma & $\begin{array}{l}\text { pemetrexed, cisplatin, } \\
\text { gemcitabine }\end{array}$ \\
\hline 7 & Breast & $\begin{array}{l}\text { epirubicin, } \\
\text { cyclophosphamide, } \\
\text { docetaxel }\end{array}$ \\
\hline 8 & Breast & $\begin{array}{l}\text { adriamycin, paclitaxel, } \\
\text { cyclophosphamide, } \\
\text { capecitabine }\end{array}$ \\
\hline 9 & Breast & $\begin{array}{l}\text { epirubicin, } \\
\text { cyclophosphamide, } \\
\text { docetaxel }\end{array}$ \\
\hline 10 & Lung & $\begin{array}{l}\text { pemetrexed, carboplatin, } \\
\text { vinorelbine }\end{array}$ \\
\hline 11 & Breast & $\begin{array}{l}\text { adriamycin, paclitaxel, } \\
\text { cyclophosphamide, } \\
\text { capecitabine }\end{array}$ \\
\hline 12 & Lung & paclitaxel, carboplatin \\
\hline 13 & Breast & $\begin{array}{l}\text { adriamycin, paclitaxel, } \\
\text { cyclophosphamide, } \\
\text { capecitabine }\end{array}$ \\
\hline
\end{tabular}

*Second-line chemotherapy regimen. for self-rated quality of life (at one month $3.9 \pm 1.2$ and at two months $4.6 \pm 1.0$ vs. baseline $2.0 \pm 0.8 ; p=0.002$ and $p=0.001$, respectively).

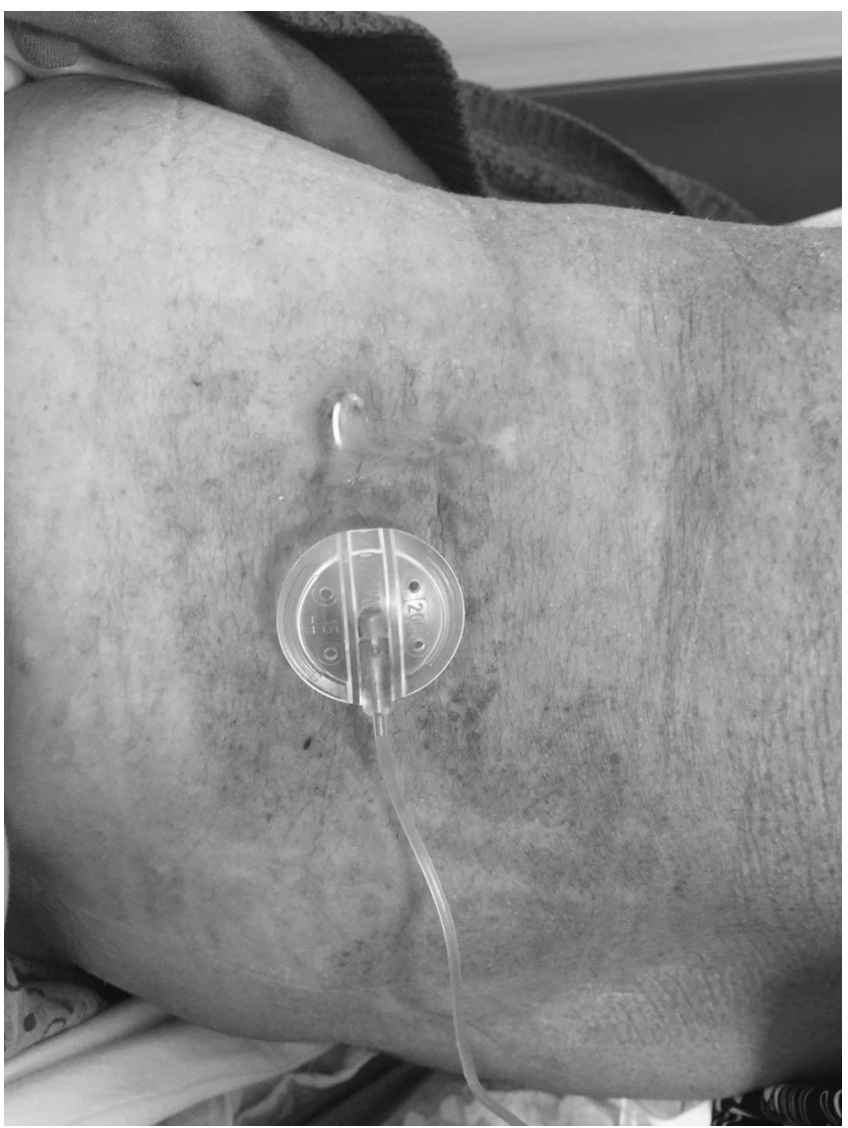

Figure 4. Foreign-body reaction with extruded catheter. 


\section{DISCUSSION}

Leptomeningeal metastases (LM) of solid tumors form a major therapeutic challenge and they are highly resistant to systemic treatments. Furthermore, patients with such conditions commonly experience severe neurological problems. In our study, encouraging results were obtained, particularly in terms of safety, among LM patients who received chemotherapy through a lumbar intrathecal port (LIP), at doses similar to those used with an Ommaya catheter. To our knowledge, this was the first report of chemotherapy administered via LIP among patients with LM.

Several studies on the efficacy and safety of chemotherapy administered through an Ommaya reservoir or through lumbar puncture, among patients with leptomeningeal metastases, have now been published. For example, in the largest systematic review investigating complications associated with the use of Ommaya reservoirs or repeated lumbar punctures, a total of 158 complications were identified in a total of 1831 Ommaya reservoir applications performed within the past 10-year period, thus corresponding to a complication rate of $8.63 \%^{20}$. The most commonly reported complications included malposition/malfunction in 30 cases, neurological complications in 28 cases, cerebrospinal fluid leakage in 24 cases and intracranial hemorrhage in 15 cases $^{20}$. Non-infectious complications due to lumbar puncture were much more common than infectious complications ${ }^{20}$. Out of a total of 1721 single punctures, there were 201 cases of complications ${ }^{20}$. The most frequent complications reported were headaches (77/201) and nausea/vomiting (49/201); however, more serious complications included epidural hematomas, chemical arachnoiditis and increased intracranial hypertension ${ }^{20}$. In terms of infections, the average percentage of infectious complications associated with Ommaya reservoirs per study was $10.9 \% \pm 1.6$, and the average percentage of infectious complications associated with lumbar punctures per study was $0.2 \% \pm 0.2^{20}$. Despite these unfavorable complication rates, the authors of that systematic review concluded that these treatments should remain in use, considering the limited survival and high morbidity rates in patients with leptomeningeal metastases.

In a series of 501 patients, Szvalb et al. found that the rate of infections associated with Ommaya reservoirs was $8 \%$ (40 patients) ${ }^{21}$. In a single center study, Zairi et al. observed complications in 11 out of 112 patients (9.8\%) with solid tumors who were treated due to leptomeningeal metastases ${ }^{10}$. Overall, there were seven cases of infections (6.2\%), two instances of symptomatic leukoencephalopathy (1.8\%), one intracranial hematoma $(0.9 \%)$ and one malpositioned catheter $(0.9 \%)^{10}$.

One relatively new method for cancer pain management consists of establishing a connection between "an intrathecal catheter" and a subcutaneous automatic infusion pump. This technique, which was originally designed for opioid and baclofen infusions, was first used in $1990^{22}$. On the other hand, subcutaneous tunneling of an intrathecal catheter to link up with external infusion pumps or a subcutaneous port (as in our method) is much older, and has been used for pain management in patients with or without cancer ${ }^{23}$.

In a meta-analysis and systematic review, Aprili et al. reported an infection incidence of $1.4 \%$ for deep tissue planes through use of lumbar intrathecal catheters for pain treatment, while the reported rate of bleeding and neurological injury was $0.9 \%{ }^{24}$. Similar to our approach, Holmfred et al. reported on the use of intrathecal catheters and subcutaneous ports for pain management at home or in hospital settings and concluded that even antibiotic prophylaxis may not be required in these patients, since only $2 \%$ of the procedures were associated with infections ${ }^{25}$.

In the present study, the complication rate seemed relatively low, compared with other reports on intrathecal chemotherapy administration techniques: i.e., no infection, technical problem, hemorrhage or malposition, although a foreign-body reaction was observed in one patient (7.7\%). However, it should be noted that our overall number of interventions was much lower than in other reports. Thus, further large studies using this technique are warranted, in order to draw firm conclusions regarding complication rates.

Until now, no superiority of chemotherapy administered through the ventricular route has not been seen to be superior to that administered through the lumbar route could be shown ${ }^{6}$. However, a subgroup analysis in one randomized trial suggested that administration of methotrexate through the ventricles may be more advantageous in terms of survival ${ }^{8}$.

Despite the limited median survival among patients with LM, specific therapies may offer a certain level of neural function protection ${ }^{26}$. Palliative treatments of the central nervous system directed towards preserving neurological functions may improve the quality of life of patients with LM, albeit for a limited period of time ${ }^{6}$. The benefits observed in our patient group mainly included reduced head and neck pain; decreased nausea/vomiting; better control of epileptic seizures, allodynia and hyperalgesia; and even improvement of mental changes and gait/sitting disturbance in some patients.

In contrast with the short duration of average survival ( 6 to 8 weeks in LM patients), it may be possible to prolong survival by around 1.75 to 4.5 months, 3-6 months or 1.7-2.5 months among patients with primary breast cancer, lung cancer or melanoma, respectively, by administering tumor-specific treatments ${ }^{6}$. In our series, the estimated median overall survival was 136 days, which is an acceptable result consistent with the published data ${ }^{5,627-36}$. This suggests that chemotherapy through LIP may offer not only a safe but also an effective therapeutic strategy in these settings. The relatively low complication rate and improved patient compliance might have contributed to the encouraging overall survival rate observed in this study.

One of the mechanisms potentially responsible for favorable observations regarding the use of the LIP method involves elimination of the need for repeated punctures for chemotherapy and cerebrospinal fluid sampling, once a single port has been 
placed. Obviating the need for repeated procedures is likely to reduce the risk of recurrent complications. Furthermore, this technique may help prevent treatment interruption due to recurrent complications; thus, it has the potential to improve efficacy. The LIP position can easily be attained and confirmed under fluoroscopy guidance, thus enabling use of effective doses at the desired site of action, again potentially increasing the treatment success and decreasing adverse effects. One other explanation for the potential success of LIP may relate to the fact that interventions involving the lumbar area are generally safer and easier than intracranial interventions. One other possible potential use of LIP may consist of using the device for CSF cytology sampling. Although the efficacy and safety of such use is outside of the scope of this study, it is worth noting that we were able to obtain CSF cytology samples through LIP, from our patients during the study period, when necessary.

There is a general tendency in oncology units worldwide to avoid repeated lumbar punctures and use Ommaya reservoirs, due to issues associated with the risk of serious side effects, technical challenges, patient compliance and cost-effectiveness. In this regard, LIP may offer an effective, safe and cost-effective alternative to the Ommaya technique that may allow more widespread availability of intrathecal treatments for patients in need of it. On the other hand, LIP seems to be most suitable when frequent administration of the chemotherapeutic agent is required. In cases of less frequently administered agents such as cytosine arabinoside or agents with long half-life, the benefits and disadvantages of placing LIP on an individual case basis should be considered. Using repeated lumbar punctures may be considered more cost effective in many patients when the agent is administered less frequently, e.g. every other week or less.

Despite the limited sample size of our study, our follow-up was lengthy. Obviously, there is a clear need for further and larger studies to better define the role of this technique for patients with LM. In addition, lack of comparison with the Ommaya reservoir technique represents another limitation of the current study.

In conclusion, lumbar port and catheter systems that have been used for intrathecal pain management for decades appear to offer a safe alternative for intrathecal chemotherapy among patients with leptomeningeal metastases. A much larger number of patients may have access to this treatment, given the very low risk of complications, high patient compliance, familiarity of anesthesiologists with the technique and cost advantages.

\section{ACKNOWLEDGEMENTS}

The authors wish to thank Figen Hanagasi, MD, from the neurology department and Kourosh Yaghoiti, MD, from the radiology department for their contributions of providing additional supplementary patient data for this study.

\section{REFERENCES}

1. Suh JH, Kotecha R, Chao ST, Ahluwalia MS, Sahgal A, Chang EL. Current approaches to the management of brain metastases. Nat Rev Clin Oncol. 2020 May;17(5):279-99. https://doi.org/10.1038/ s41571-019-0320-3

2. Scoccianti S, Ricardi U. Treatment of brain metastases: review of phase III randomized controlled trials. Radiother Oncol. 2012 Feb;102(2):168-79. https://doi.org/10.1016/j.radonc.2011.08.041

3. Chamberlain MC. Leptomeningeal metastasis. Curr Opin Oncol. 2010 Nov;22(6):627-35. https://doi.org/10.1097/CC0.0b013e32833de986

4. Le Rhun E, Taillibert S, Chamberlain MC. Carcinomatous meningitis: Leptomeningeal metastases in solid tumors. Surg Neurol Int. 2013 May 2;4(Suppl 4):S265-88. https://doi.org/10.4103/21527806.111304

5. Thakkar JP, Kumthekar P, Dixit KS, Stupp R, Lukas RV. Leptomeningeal metastasis from solid tumors. J Neurol Sci. 2020 Apr 15;411:116706. https://doi.org/10.1016/j.jns.2020.116706

6. Le Rhun E, Weller M, Brandsma D, Van den Bent M, de Azambuja E, Henriksson R, et al. EANO-ESMO clinical practice guidelines for diagnosis, treatment and follow-up of patients with leptomeningeal metastasis from solid tumours. Ann Oncol. $2017 \mathrm{Jul}$ 1;28 Suppl 4:iv84-99. https://doi.org/10.1093/annonc/mdx221

7. Zagouri F, Zoumpourlis P, Le Rhun E, Bartsch R, Zografos E, Apostolidou K, et al. Intrathecal administration of anti-HER2 treatment for the treatment of meningeal carcinomatosis in breast cancer: a metanalysis with meta-regression. Cancer Treat Rev. 2020 Aug;88:102046. https://doi.org/10.1016/j.ctrv.2020.102046

8. Glantz MJ, Van Horn A, Fisher R, Chamberlain MC. Route of intracerebrospinal fluid chemotherapy administration and efficacy of therapy in neoplastic meningitis. Cancer. 2010 Apr 15;116(8):194752. https://doi.org/10.1002/cncr.24921

9. Shapiro WR, Schmid M, Glantz M, Miller JJ. A randomized phase III/ IV study to determine benefit and safety of cytarabine liposome injection for treatment of neoplastic meningitis. J Clin Oncol. 2006 Jun 20;24(18):1528-28. https://doi.org/10.1200/jco.2006.24.18_ suppl.1528

10. Zairi F, Le Rhun E, Bertrand N, Boulanger T, Taillibert S, Aboukais R, et al. Complications related to the use of an intraventricular access device for the treatment of leptomeningeal metastases from solid tumor: a single centre experience in 112 patients. J Neurooncol. 2015 Sep;124(2):317-23. https://doi.org/10.1007/s11060-015-1842-x

11. Kennedy BC, Brown LT, Komotar RJ, McKhann GM 2nd. Stereotactic catheter placement for Ommaya reservoirs. J Clin Neurosci. 2016 May 1;27:44-7. https://doi.org/10.1016/j.jocn.2015.11.005

12. Morgenstern PF, Connors S, Reiner AS, Greenfield JP. Image guidance for placement of Ommaya reservoirs: comparison of fluoroscopy and frameless stereotactic navigation in 145 patients. World Neurosurg. 2016 Sep;93:154-8. https://doi.org/10.1016/j.wneu.2016.04.090

13. Major K, Schlauderaff A, Brawley A, Hale DE, Rizk E. Safe placement of Ommaya reservoirs in Thrombocytopenic patients: one institutions experience. Cureus. 2019 Jul 31;11(7):e5291. https://doi.org/10.7759/ cureus.5291

14. Chamberlain MC, Kormanik PA, Barba D. Complications associated with intraventricular chemotherapy in patients with leptomeningeal metastases. J Neurosurg. 1997 Nov;87(5):694-9. https://doi. org/10.3171/jns.1997.87.5.0694

15. Lau JC, Kosteniuk SE, Macdonald DR, Megyesi JF. Image-guided 
Ommaya reservoir insertion for intraventricular chemotherapy: a retrospective series. Acta Neurochir (Wien). 2018 Mar;160(3):539-44. https://doi.org/10.1007/s00701-017-3454-z

16. Shapiro WR, Young DF, Mehta BM. Methotrexate: distribution in cerebrospinal fluid after intravenous, ventricular and lumbar injections. N Engl J Med. 1975 Jul 24;293(4):161-6. https://doi. org/10.1056/NEJM197507242930402

17. Krames ES, Gershow J, Glassberg A, Kenefick T, Lyons A, Taylor P, et al. Continuous infusion of spinally administered narcotics for the relief of pain due to malignant disorders. Cancer. 1985 Aug 1;56(3):696702. https://doi.org/10.1002/1097-0142(19850801)56:3<696::aidcncr2820560343>3.0.c0;2-8

18. Oken MM, Creech RH, Tormey DC, Horton J, Davis TE, McFadden ET, et al. Toxicity and response criteria of the Eastern Cooperative Oncology Group. Am J Clin Oncol. 1982 Dec;5(6):649-55.

19. National Cancer Institute. Common Terminology Criteria for Adverse Events (CTCAE) Version 5.0. Washington (DC): U.S. Department of Health and Human Services; 2017. Available from: https://ctep. cancer.gov/protocoldevelopment/electronic_applications/docs/ CTCAE_v5_Quick_Reference_8.5x11.pdf

20. Ali A, Bosse RC, Doonan BP, Narayan P, Jester GA, Delaune JD, et al. Ommaya reservoir related complications: a single center experience and review of current literature. Int J Clin Oncol Cancer Res. 2019 Apr;4(2):10-24. https://doi.org/10.11648/j.ijcocr.20190402.12

21. Szvalb AD, Raad, II, Weinberg JS, Suki D, Mayer R, Viola GM. Ommaya reservoir-related infections: clinical manifestations and treatment outcomes. J Infect. 2014 Mar;68(3):216-24. https://doi.org/10.1016/j. jinf.2013.12.002

22. Onofrio BM, Yaksh TL. Long-term pain relief produced by intrathecal morphine infusion in 53 patients. J Neurosurg. 1990 Feb;72(2):200-9. https://doi.org/10.3171/jns.1990.72.2.0200

23. Smyth C, Ahmadzai N, Wentzell J, Pardoe A, Tse A, Nguyen T, et al. Intrathecal analgesia for chronic refractory pain: current and future prospects. Drugs. 2015 Nov;75(17):1957-80. https://doi.org/10.1007/ s40265-015-0471-1

24. Aprili D, Bandschapp O, Rochlitz C, Urwyler A, Ruppen W. Serious complications associated with external intrathecal catheters used in cancer pain patients: a systematic review and meta-analysis. Anesthesiology. 2009 Dec;111(6):1346-55. https://doi.org/10.1097/ ALN.0b013e3181bfab9a

25. Holmfred A, Vikerfors T, Berggren L, Gupta A. Intrathecal catheters with subcutaneous port systems in patients with severe cancerrelated pain managed out of hospital: the risk of infection. J Pain Symptom Manage. 2006 Jun 1;31(6):P568-72. https://doi. org/10.1016/j.jpainsymman.2005.11.010

26. 26. Park JH, Kim YJ, Lee J-O, Lee K-W, Kim JH, Bang S-M, et al.
Clinical outcomes of leptomeningeal metastasis in patients with non-small cell lung cancer in the modern chemotherapy era. Lung Cancer. 2012 Jun 1;76(3):P387-92. https://doi.org/10.1016/j. lungcan.2011.11.022

27. Franzoi MA, Hortobagyi GN. Leptomeningeal carcinomatosis in patients with breast cancer. Crit Rev Oncol Hematol. 2019 Mar;135:85-94. https://doi.org/10.1016/j.critrevonc.2019.01.020

28. Lara-Medina F, Crismatt A, Villarreal-Garza C, Alvarado-Miranda A, Flores-Hernandez L, Gonzalez-Pinedo M, et al. Clinical features and prognostic factors in patients with carcinomatous meningitis secondary to breast cancer. Breast J. 2012 May-Jun;18(3):233-41. https://doi.org/10.1111/j.1524-4741.2012.01228.x

29. Rudnicka H, Niwińska A, Murawska M. Breast cancer leptomeningeal metastasis--the role of multimodality treatment. J Neurooncol. 2007 Aug;84(1):57-62. https://doi.org/10.1007/s11060-007-9340-4

30. Le Rhun E, Taillibert S, Zairi F, Kotecki N, Devos P, Mailliez A, et al. A retrospective case series of 103 consecutive patients with leptomeningeal metastasis and breast cancer.J Neurooncol. 2013 May;113(1):83-92. https://doi.org/10.1007/s11060-013-1092-8

31. Niwińska A, Rudnicka H, Murawska M. Breast cancer leptomeningeal metastasis: the results of combined treatment and the comparison of methotrexate and liposomal cytarabine as intra-cerebrospinal fluid chemotherapy. Clin Breast Cancer. 2015 Feb 1;15(1):P66-72. https://doi.org/10.1016/j.clbc.2014.07.004

32. Lee SJ, Lee J-I, Nam D-H, Ahn YC, Han JH, Sun J-M, et al. Leptomeningeal carcinomatosis in non-small-cell lung cancer patients: impact on survival and correlated prognostic factors. J Thorac Oncol. 2013 Feb 1;8(2):P185-91. https://doi.org/10.1097/ JTO.0b013e3182773f21

33. Kuiper JL, Hendriks LE, van der Wekken AJ, de Langen AJ, Bahce I, Thunnissen E, et al. Treatment and survival of patients with EGFRmutated non-small cell lung cancer and leptomeningeal metastasis: a retrospective cohort analysis. Lung Cancer. 2015 Sep 1;89(3):P25561. https://doi.org/10.1016/j.lungcan.2015.05.023

34. Riess JW, Nagpal S, Iv M, Zeineh M, Gubens MA, Ramchandran K, et al. Prolonged survival of patients with non-small-cell lung cancer with leptomeningeal carcinomatosis in the modern treatment era. Clin Lung Cancer. 2014 May 1;15(3):P202-6. https://doi.org/10.1016/j. cllc.2013.12.009

35. Ferguson SD, Bindal S, Bassett Jr RL, Haydu LE, McCutcheon IE, Heimberger AB, et al. Predictors of survival in metastatic melanoma patients with leptomeningeal disease (LMD). J Neurooncol. 2019 May 1;142(3):499-509. https://doi.org/10.1007/s11060-019-03121-2

36. Foppen MHG, Brandsma D, Blank CU, van Thienen JV, Haanen JB, Boogerd W. Targeted treatment and immunotherapy in leptomeningeal metastases from melanoma. Ann Oncol. 2016 Jun 1;27(6):1138-42. https://doi.org/10.1093/annonc/mdw134 